HETEROCYCLES, Vol. 102, No. 10, 2021, pp. 1995 - 2006. @ 2021 The Japan Institute of Heterocyclic Chemistry Received, 15th June, 2021 Accepted, 6th July,2021 Published online, 19th July, 2021. DOI: $10.3987 / C O M-21-14506$

\title{
WHEN HYDRAZONOYL CHLORIDES MEET ALLENES: A SITE- AND REGIO-SELECTIVE COPPER(I)-CATALYSED APPROACH TO 5-SUBSTITUTED PYRAZOLES
}

\section{Giorgio Molteni,* Stefano Baroni, Marco Manenti, and Alessandra Silvani}

State University of Milan, Department of Chemistry, via Golgi 19, 20133, Milan, Italy, e-mail address giorgio.molteni@unimi.it

\begin{abstract}
The reaction between hydrazonoyl chlorides and monosubstituted allenes in the presence of catalytic amounts of copper(I) chloride gives 1,3,5-substituted pyrazoles under mild conditions and very short reaction times. This site- and regioselective process involves first the complexation of copper(I) on the external double bond of the allene moiety, followed by nucleophilic attack on the central carbon atom of the so-formed copper(I)-complexed allene by the terminal nitrogen of the hydrazonoyl chloride. Subsequent ring closure to the target pyrazole ring is possible in the presence of electron-attracting groups on the allene moiety. A catalytic cycle has been proposed on the basis of the experimental results.
\end{abstract}

Allenes can undergo a wide variety of reactions ${ }^{1}$ including the celebrated Diels-Alder $^{1,2}$ and 1,3-dipolar ${ }^{3}$ cycloadditions. To this latter respect, allenes are particularly interesting dipolarophiles as they have two sites of addition, for each of which two different dipole-dipolarophile orientations are possible. Several years ago, one of us was engaged in the synthesis of highly-functionalised pyrazoles by cycloaddition between allenes and nitrilimines, ${ }^{4}-\mathrm{C} \equiv \mathrm{N}^{+}-\mathrm{N}^{-}$, owing to the fact that variously functionalised pyrazoles are interesting targets in medicinal chemistry as analgesic, antifungal, anti-inflammatory, antibacterial and antiviral agents. ${ }^{5}$ Unfortunately, it was found that the obtainment of complex reaction mixtures was often the rule, i.e. the cycloaddition showed poor site- and regio-selectivity. Furthermore, the reaction outcome was strongly dependent on the electronic nature of the 1,3-dipole: while electron-rich nitrilimines gave fair results, the cycloaddition pathway appeared impervious with electron-poor nitrilimines. Since the in situ generation of the labile nitrilimine intermediate was accomplished by dehydrohalogenation of the corresponding hydrazonoyl chloride $-\mathrm{C}(\mathrm{Cl})=\mathrm{N}-\mathrm{NH}-$ with stoichiometric amounts of silver carbonate, ${ }^{4,6}$ it is apparent that a site- and regio-selective approach to the pyrazole ring 
that avoids the generation of the labile nitrilimine intermediate starting from hydrazonoyl chlorides would be highly valuable. To this purpose, the present paper deals with the behaviour of hydrazonoyl chlorides 1a-d towards allenes $\mathbf{2 a - e}$ in the presence of catalytic amounts of copper(I) salts.

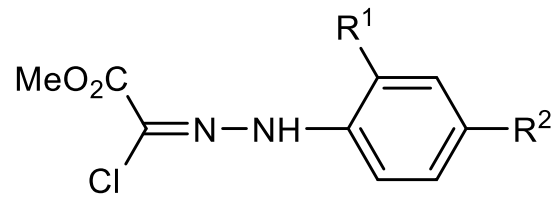

1

$$
\begin{aligned}
& \text { 1a: } R^{1}=R^{2}=H \\
& \text { 1b: } R^{1}=H, R^{2}=F \\
& \text { 1c: } R^{1}=H, R^{2}=N_{2} \\
& \text { 1d: } R^{1}=M e, R^{2}=H
\end{aligned}
$$

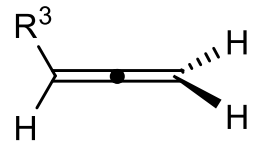

2

Figure 1. Hydrazonoyl chlorides 1a-d and allenes 2a-e used as reactants

The search for the best reaction conditions was carried out by investigating the behaviour of ethyl buta-2,3-dienoate (2a) towards hydrazonoyl chloride (1a) in the presence of a metal salt and a basic agent (Scheme 1, Table 1). Since no reaction occurred by stirring a solution of the reagents at $20{ }^{\circ} \mathrm{C}$ for $48 \mathrm{~h}$ (Table 1, entry 1), the nitrilimine intermediacy can be safely ruled out for shorter reaction times at room temperature. Small quantitites of the target pyrazole (3aa) were obtained in the presence of stoichiometric amounts of silver(I) salts (Table 1, entries 2-5), this finding is consistent to the prolonged reaction times usually required for this kind of reaction. ${ }^{4}$ This discouraging picture changed by using a catalytic amount of copper(I) salt (Table 1, entries 6-14). As it can be seen from Table 1, entry 10, the best result was obtained with $\mathrm{CuCl}$ in dichloromethane at $20{ }^{\circ} \mathrm{C}$. By adding $\mathrm{CuCl}$ to a colourless solution of ethyl buta-2,3-dienoate and triethylamine, a pale yellow-green suspension appeared suggesting the formation of some kind of copper(I) complex (vide infra). Immediately after the subsequent addition of a solution of 1a, the reaction mixture turned into a pale brown suspension. As preliminar remarks, it can be noted that the overall transformation $\mathbf{1 a} \rightarrow$ 3aa is poorly affected by the base (Table 1, entries 6-8) while it appears faster in low-polar solvents, suggesting that any reaction intermediate could have similar polarity to the reactants. As far as the copper(I) salts are concerned, it is likely that their solubilities in dichloromethane slightly affects the reaction rate (Table 1 , entries 10-14). 


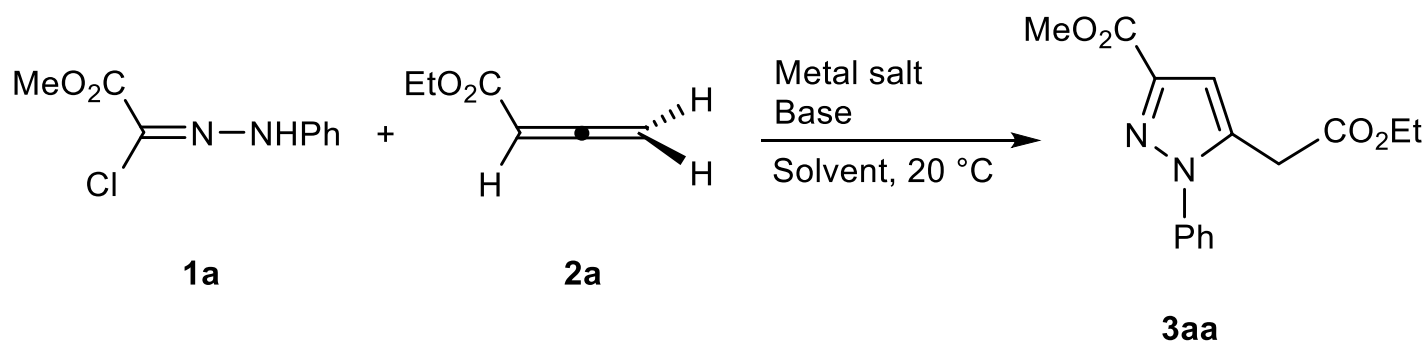

Scheme 1. Reaction between hydrazonoyl chloride (1a) and ethyl buta-2,3-dienoate (2a)

Table 1. Reaction between hydrazonoyl chloride (1a) and ethyl buta-2,3-dienoate (2a) at $20{ }^{\circ} \mathrm{C}$

\begin{tabular}{|c|c|c|c|c|c|}
\hline Entry & Metal salt (equiv.) & Base (equiv.) & Solvent & Time (h) & $\mathbf{3 a a}(\%)^{\mathbf{a}}$ \\
\hline 1 & - & $\mathrm{Et}_{3} \mathrm{~N}(2)$ & toluene & 48 & - \\
\hline 2 & $\mathrm{Ag}_{2} \mathrm{O}(1)$ & $\mathrm{Et}_{3} \mathrm{~N}(1)$ & toluene & 24 & $7^{\mathbf{b}}$ \\
\hline 3 & $\operatorname{AgOAc}(1)$ & $\mathrm{Et}_{3} \mathrm{~N}$ & EtOAc & 24 & $11^{b}$ \\
\hline 4 & $\mathrm{Ag}_{2} \mathrm{CO}_{3}(2)$ & - & 1,4-dioxane & 24 & $12^{\mathbf{b}}$ \\
\hline 5 & $\mathrm{Ag}_{2} \mathrm{CO}_{3}(2)$ & - & $\mathrm{CH}_{2} \mathrm{Cl}_{2}$ & 24 & $9^{\mathbf{b}}$ \\
\hline 6 & $\mathrm{CuCl}(0.1)$ & DABCO (1) & toluene & 1 & 73 \\
\hline 7 & $\mathrm{CuCl}(0.1)$ & DBU (1) & toluene & 1 & 76 \\
\hline 8 & $\mathrm{CuCl}(0.1)$ & $\mathrm{Et}_{3} \mathrm{~N}(1)$ & toluene & 0.75 & 78 \\
\hline 9 & $\mathrm{CuCl}(0.1)$ & $\mathrm{Et}_{3} \mathrm{~N}$ & $\mathrm{DMF}$ & 1.5 & 70 \\
\hline 10 & $\mathrm{CuCl}(0.07)$ & $\mathrm{Et}_{3} \mathrm{~N}$ & $\mathrm{CH}_{2} \mathrm{Cl}_{2}$ & 0.25 & 82 \\
\hline 11 & $\mathrm{CuBr}(0.1)$ & $\mathrm{Et}_{3} \mathrm{~N}$ & $\mathrm{CH}_{2} \mathrm{Cl}_{2}$ & 0.5 & 76 \\
\hline 12 & $\mathrm{CuI}(0.1)$ & $\mathrm{Et}_{3} \mathrm{~N}$ & $\mathrm{CH}_{2} \mathrm{Cl}_{2}$ & 1 & 71 \\
\hline 13 & $\mathrm{Cu}_{2} \mathrm{O}(0.2)$ & $\mathrm{Et}_{3} \mathrm{~N}(1)$ & $\mathrm{CH}_{2} \mathrm{Cl}_{2}$ & 2.5 & 73 \\
\hline 14 & $\mathrm{CuOAc}(0.1)$ & $\mathrm{Et}_{3} \mathrm{~N}$ & $\mathrm{CH}_{2} \mathrm{Cl}_{2}$ & 0.5 & $56^{\mathrm{b}}$ \\
\hline
\end{tabular}

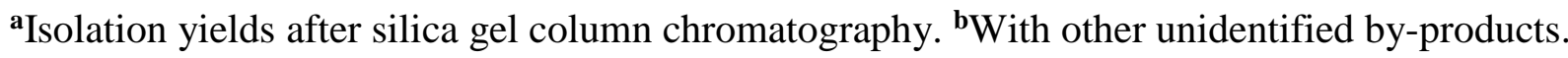

The optimised reaction conditions were applied to the hydrazonoyl chlorides 1a-d and allenes 2a-e showed in Figure 1. Most of the reactions listed in Scheme 2 and Table 2 (entries 1-12) were fully siteand regio-selective giving the 5-substituted pyrazoles 3 in 10-30 min with satisfactory isolation yields (72-83\%), irrespective to the substituents $\mathrm{R}^{1}-\mathrm{R}^{3}$, although small amounts of tarry material were usually formed. In the case of the two allenes $\mathbf{2 d}$,e bearing electro-neutral or electro-donating groups, respectively, it was not possible to isolate the correponding pyrazole adduct since their extensive decomposition took place (Table 2, entries 13,14). 

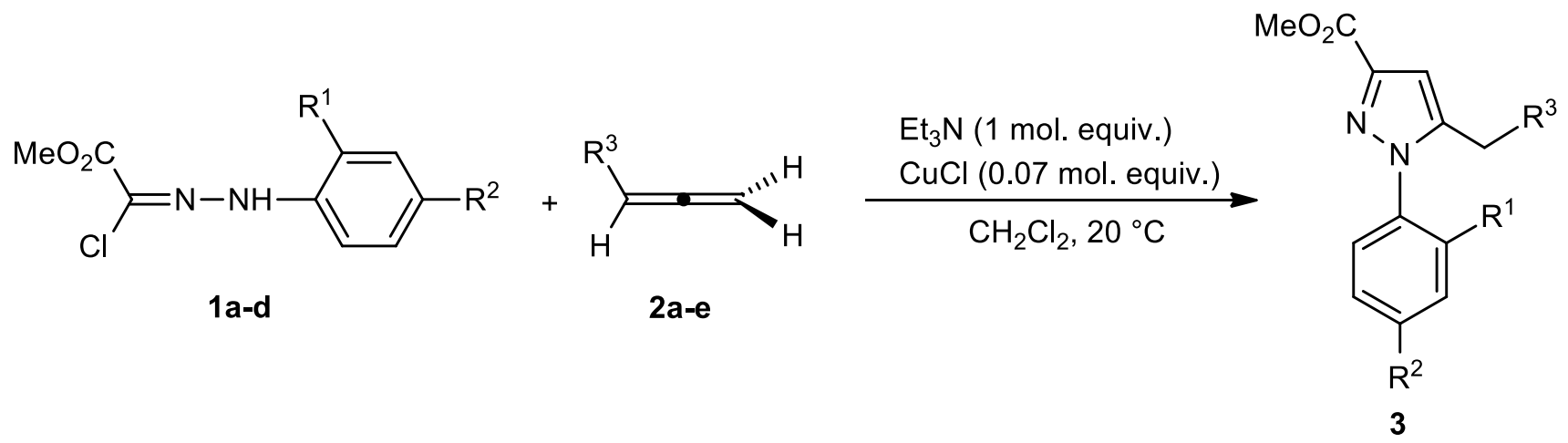

Scheme 2. Reaction between hydrazonoyl chlorides 1a-d and allenes 2a-e

Table 2. Reaction between hydrazonoyl chlorides 1a-d and allenes 2a-e

\begin{tabular}{|c|c|c|c|c|c|c|}
\hline Entry & $\mathrm{R}^{1}$ & $\mathrm{R}^{2}$ & $\mathrm{R}^{3}$ & Product & $\begin{array}{l}\text { Time } \\
\text { (min.) }\end{array}$ & $\begin{array}{c}\text { Yield }^{\mathrm{a}} \\
(\%)\end{array}$ \\
\hline 1 & $\mathrm{H}$ & $\mathrm{H}$ & $\mathrm{CO}_{2} \mathrm{Et}$ & 3aa & 15 & 82 \\
\hline 2 & $\mathrm{H}$ & $\mathrm{F}$ & $\mathrm{CO}_{2} \mathrm{Et}$ & $3 \mathbf{b a}$ & 10 & 78 \\
\hline 3 & $\mathrm{H}$ & $\mathrm{NO}_{2}$ & $\mathrm{CO}_{2} \mathrm{Et}$ & $3 \mathbf{c a}$ & 25 & 73 \\
\hline 4 & $\mathrm{Me}$ & $\mathrm{H}$ & $\mathrm{CO}_{2} \mathrm{Et}$ & 3da & 20 & 83 \\
\hline 5 & $\mathrm{H}$ & $\mathrm{H}$ & $\mathrm{SO}_{2} \mathrm{Ph}$ & 3ab & 20 & 72 \\
\hline 6 & $\mathrm{H}$ & $\mathrm{F}$ & $\mathrm{SO}_{2} \mathrm{Ph}$ & $3 b b$ & 20 & 76 \\
\hline 7 & $\mathrm{H}$ & $\mathrm{NO}_{2}$ & $\mathrm{SO}_{2} \mathrm{Ph}$ & $3 \mathrm{cb}$ & 25 & 75 \\
\hline 8 & $\mathrm{Me}$ & $\mathrm{H}$ & $\mathrm{SO}_{2} \mathrm{Ph}$ & $3 d \mathbf{b}$ & 15 & 75 \\
\hline 9 & $\mathrm{H}$ & $\mathrm{H}$ & $\mathrm{SO}_{2} \mathrm{Ar}^{\mathbf{b}}$ & $3 a c$ & 20 & 73 \\
\hline 10 & $\mathrm{H}$ & $\mathrm{F}$ & $\mathrm{SO}_{2} \mathrm{Ar}^{\mathbf{b}}$ & $3 b c$ & 20 & 80 \\
\hline 11 & $\mathrm{H}$ & $\mathrm{NO}_{2}$ & $\mathrm{SO}_{2} \mathrm{Ar}^{\mathbf{b}}$ & $3 \mathrm{cc}$ & 30 & 77 \\
\hline 12 & $\mathrm{Me}$ & $\mathrm{H}$ & $\mathrm{SO}_{2} \mathrm{Ar}^{\mathbf{b}}$ & $3 d c$ & 30 & 75 \\
\hline 13 & $\mathrm{H}$ & $\mathrm{H}$ & cyclohexyl & 3ad & 180 & $-^{\mathbf{c}}$ \\
\hline 14 & $\mathrm{H}$ & $\mathrm{H}$ & $\mathrm{OMe}$ & 3ae & 180 & $\ldots$ \\
\hline
\end{tabular}

aIsolation yields after silica gel column chromatography.

${ }^{\mathbf{b}} \mathrm{Ar}=2-\mathrm{MeCONH}-\mathrm{C}_{6} \mathrm{H}_{4}$. ${ }^{\mathrm{c}}$ Uncharacterisable tarry material.

The latter behaviour is consistent to the well-known polymerisation of allenes in the presence of metal cations, as early reports clearly indicate that cationic techniques gave uncontrolled allene oligomerization and polymerization. ${ }^{7}$ Anyway, the 5 -substituted pyrazoles (3ad) and (3ae) were obtained by reacting hydrazonoyl chloride (1a) with 3-cyclohexyl-1-propyne (4a) and methoxypropargyl ether (4b), 
respectively, in the presence of catalytic amounts of $\mathrm{CuCl}$ following a recent protocol elaborated by one of us. ${ }^{8}$ This pair of reactions is particularly relevant because it provides evidence that allene $\rightarrow$ acetylene isomerisation is suppressed under the conditions depicted in Scheme 2.

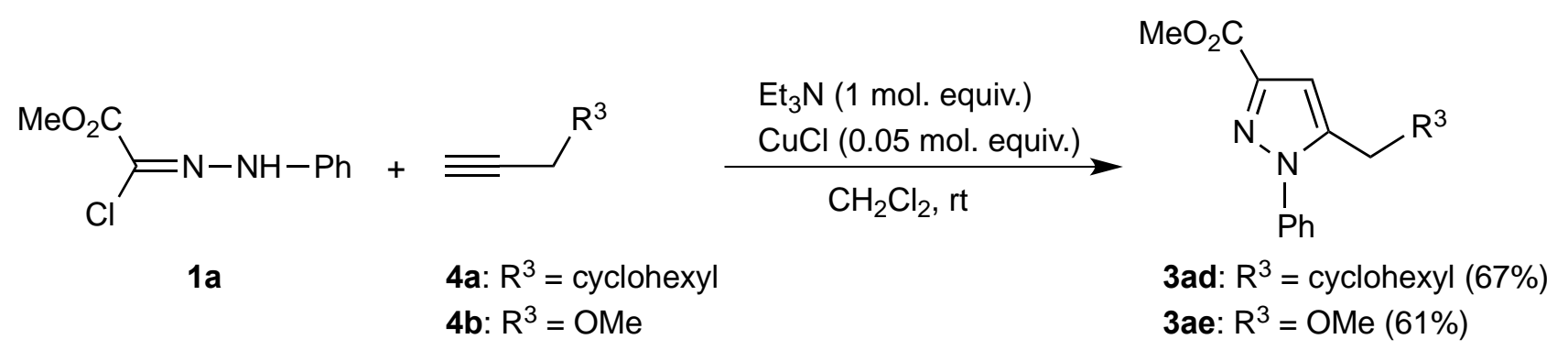

Scheme 3. CuCl-Catalysed reaction between hydrazonoyl chloride 1a and acetylenes $\mathbf{4 a , b}$

In order to rationalise the experimental results described above, the catalytic cycle depicted in Figure 2 was designed and, for the sake of clarity, it is referred to hydrazonoyl chloride (1a) and allene (2a). The first step relies upon the complexation of the $\beta, \gamma$-allene double bond by copper(I) to give the intermediate (A). A quite similar mechanistic hypothesis has been also proposed in a recent copper(I)-catalysed hydrocarboxylation of $N$-allenyl derivatives. ${ }^{9}$ This initial copper(I)-allene coordination is fully consistent to the attitude of some allenes to form well-defined crystalline $\pi$-complexes with $\mathrm{CuCl} .{ }^{10}$ Reasonably, the following nucleophilic addition of the hydrazonoyl chloride moiety could give the key metalated intermediate (B). Keto-enol isomerisation of the latter followed by ring closure restarts the catalytic cycle, while subsequent aromatisation of the 5-methylene pyrazole intermediate (E) finally gives the pyrazoles 3 . It is apparent that, due to the lack of stabilisation of the corresponding intermediates $(\mathbf{B})$ and $(\mathbf{C})$, the pathway outlined in Figure 2 is precluded to both the cyclohexyl- and methoxy-allenes 2d,e. In these cases, the uncontrolled allene polymerisation becomes the predominant reaction at the expense of pyrazole formation. Unfortunately, catalyst recovery suffers of the usual limitations of copper(I) unsupported catalysts. ${ }^{11}$ Due to the very small amount of $\mathrm{CuCl}$ and the presence of the sparingly soluble triethylammonium hydrochloride in the reaction mixture, the catalyst recovery was prevented in the depicted reaction conditions. In fact, water washing of the reaction crude should remove the triethylammonium salt causing the disproportionation of the copper(I) chloride.

As a concluding remark, a reliable protocol for the copper(I)-catalysed regioselective synthesis of 1,3,5-substituted pyrazoles was developed by using monosubstituted allenes and hydrazonoyl chlorides as the starting reagents. Compared to the corresponding nitrilimine-allene cycloadditions, the present procedure features mild reaction conditions and short reaction times, leading to satisfactory product yields 
with full site- and regio-selectivity. All the experimental findings were rationalised through a novel catalytic cycle.

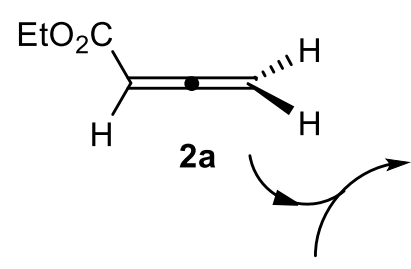

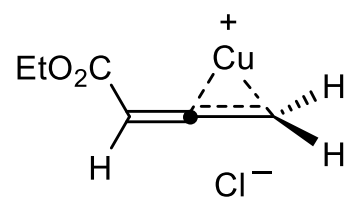

A

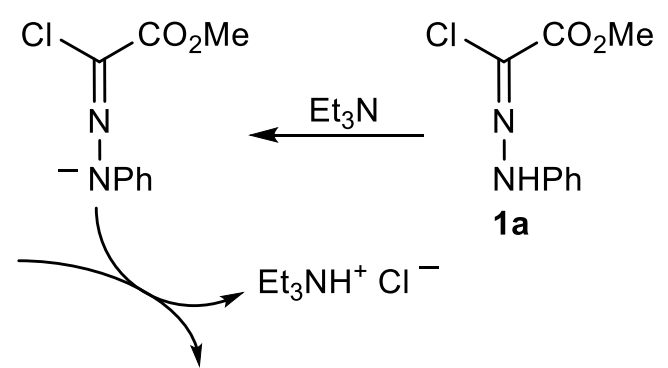

$\mathrm{CuCl}$<smiles>CCOC(=O)Cc1cc(C(=O)OCC)nn1-c1ccccc1</smiles><smiles>CCOC1CCCCC1N(/N=C(\Cl)COC)c1ccccc1</smiles>

3aa

Figure 2. Proposed catalytic cycle for the reaction $\mathbf{1 a}+\mathbf{2 a} \rightarrow \mathbf{3 a a}$

\section{EXPERIMENTAL}

General. Melting points were determined on a Büchi apparatus in open tubes and are uncorrected. IR spectra were recorded on a PerkinElmer 1725 X spectrophotometer. Mass spectra were determined on a VG-70EQ apparatus. ${ }^{1} \mathrm{H}-\mathrm{NMR}(300 \mathrm{MHz}),{ }^{13} \mathrm{C}-\mathrm{NMR}(75 \mathrm{MHz})$ and ${ }^{19} \mathrm{~F}-\mathrm{NMR}(282 \mathrm{MHz})$ spectra were taken with a Bruker Avance instrument (in $\mathrm{CDCl}_{3}$ solutions at room temperature). Chemical shifts are given as parts per million from tetramethylsilane. Coupling constants $(J)$ values are given in hertz and are quoted to $\pm 0.1 \mathrm{~Hz}$ consistently with NMR machine accuracy. All solvents and reagents were purified by standard technique or used as supplied from chemical sources as appropriate. Reagent chemicals were purchased from Aldrich Chemical Company Ltd. Solvents were dried and stored over $4 \AA$ molecular sieves prior to use. 
Hydrazonoyl chlorides $\mathbf{1 a - \mathbf { d } ^ { 1 2 }}$ and allenes $\mathbf{2} \mathbf{b}$ and $\mathbf{2} \mathbf{c}^{13}$ were prepared according to literature procedures. 1,3,5-Substituted pyrazoles $\mathbf{3} \mathbf{a} \mathbf{b}^{14}$ and $\mathbf{3} \mathbf{a} \mathbf{c}^{4}$ are known in the literature.

Uncatalysed treatment of hydrazonoyl chloride (1a) with ethyl buta-2,3-dienoate (2a) (Table 1, entry 1). A solution of hydrazonoyl chloride (1a) $(0.42 \mathrm{~g}, 2.0 \mathrm{mmol})$ in toluene $(4 \mathrm{~mL})$ was added to a solution of ethyl buta-2,3-dienoate (2a) $(0.23 \mathrm{~g}, 2.0 \mathrm{mmol})$ and triethylamine $(0.40 \mathrm{~g}, 4.0 \mathrm{mmol})$ in dry toluene $(4 \mathrm{~mL})$, and stirred for $48 \mathrm{~h}$ at $20^{\circ} \mathrm{C}$. The resulting solution was submitted to TLC analysis with hexane/EtOAc 3:2 showing traces of pyrazole (3aa), $R_{f}=0.28$. Evaporation of such solution under reduced pressure gave the starting hydrazonoyl chloride (1a) $(0.36 \mathrm{~g}, 85 \%)$.

Metal-catalysed reaction between hydrazonoyl chloride (1a) and ethyl buta-2,3-dienoate (2a). General procedure. In a clear, colourless solution of ethyl buta-2,3-dienoate (2a) $(0.23 \mathrm{~g}, 2.0 \mathrm{mmol})$ and the appropriate base (equiv. as in Table 1) in dry solvent (4 mL, Table 1) was added the appropriate metal salt (equiv. as in Table 1) under vigorous magnetic stirring obtaining a subspension. A solution of the hydrazonoyl chloride (1a) $(0.42 \mathrm{~g}, 2.0 \mathrm{mmol})$ in the appropriate solvent $(4 \mathrm{~mL}$, Table 1) was added dropwise to the subspension and the mixture was stirred at $20{ }^{\circ} \mathrm{C}$ for the time indicated in Table 1 . The crude was filtered over a silica gel pad and the solvent was evaporated under reduced pressure.

In the case of entries 2-14 of Table 1, the residue was chromatographed on a silica gel column with hexane/EtOAc 3:2. First fractions contained starting 1a, further elution gave the pyrazole (3aa). Subsequent crystallisation with $i \operatorname{Pr}_{2} \mathrm{O}$ gave pure 3aa with the yields listed in Table 1 .

1-Phenyl-3-methoxycarbonyl-5-(ethoxycarbonyl)methylpyrazole (3aa). Pale yellow powder having mp 111-113 ${ }^{\circ} \mathrm{C}$; IR (Nujol): $1735(>\mathrm{C}=\mathrm{O})\left(\mathrm{cm}^{-1}\right)$; ${ }^{1} \mathrm{H}-\mathrm{NMR}: 2.20\left(3 \mathrm{H}, \mathrm{t}, J=6.0,-\mathrm{OCH}_{2} \mathrm{C}_{3}\right), 3.69(2 \mathrm{H}, \mathrm{s}$, $\left.-\underline{\mathrm{C}}_{2} \mathrm{COO}-\right), 3.93\left(3 \mathrm{H}, \mathrm{s},-\mathrm{COOC}_{3}\right), 4.13\left(2 \mathrm{H}, \mathrm{q}, J=6.0,-\mathrm{OC}_{2} \mathrm{CH}_{3}\right), 6.94\left(1 \mathrm{H}, \mathrm{s}\right.$, pyrazole- $\left.\underline{\mathrm{H}}_{4}\right)$, 7.44-7.52 (5H, m, aromatics); ${ }^{13} \mathrm{C}-\mathrm{NMR}: 14.0$ (q, $-\mathrm{OCH}_{2} \mathrm{CH}_{3}$ ), 32.2 (t, - $\underline{\mathrm{C}}_{2} \mathrm{COO}-$ ), 52.0 (q, -COOC $\mathrm{H}_{3}$ ), $61.5\left(\mathrm{t},-\mathrm{OC}_{2} \mathrm{CH}_{3}\right), 110.1$ (d, pyrazole- $\underline{\mathrm{C}} 4$ ), 125.8-129.4 (a pair of peak at the aromatic region is

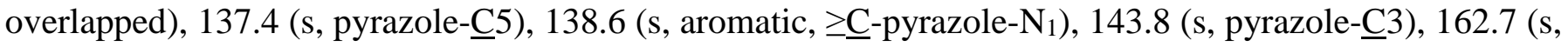

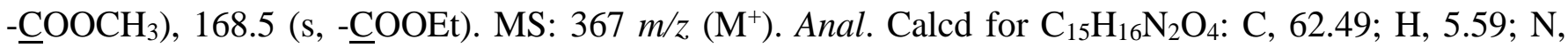
9.72. Found: C, 62.44; H, 5.63; N, 9.80.

In the case of entries 2-5 and 14 of Table 1, subsequent fractions contained traces of unidentified by-products.

Copper(I)-catalysed reaction between hydrazonoyl chlorides 1a-d and allenes 2a-e. General procedure. In a clear, colourless solution of the appropriate allene $2(2.0 \mathrm{mmol})$ and triethylamine $(0.20 \mathrm{~g}$, $2.0 \mathrm{mmol})$ in dry $\mathrm{CH}_{2} \mathrm{Cl}_{2}(4 \mathrm{~mL})$ was added $\mathrm{CuCl}(10 \mathrm{mg}, 0.1 \mathrm{mmol})$ under vigorous magnetic stirring. A 
solution of the appropriate hydrazonoyl chloride $\mathbf{1}(2.0 \mathrm{mmol})$ in dry $\mathrm{CH}_{2} \mathrm{Cl}_{2}(4 \mathrm{~mL})$ was added dropwise and the mixture was stirred at $20{ }^{\circ} \mathrm{C}$ for the time indicated in Table 2.

In the case of entries 1-12 of Table 2, the crude was filtered over a silica gel pad and the solvent was evaporated under reduced pressure. The residue was chromatographed on a silica gel column with hexane/EtOAc 2:1. Crystallisation of the eluate with $i \operatorname{Pr}_{2} \mathrm{O}$ gave pure 3 .

1-(4-Fluorophenyl)-3-methoxycarbonyl-5-(ethoxycarbonyl)methylpyrazole (3ba) (0.48 g, $78 \%$ ). Pale yellow powder having mp 102-104 ${ }^{\circ} \mathrm{C}$; IR $($ Nujol $): 1730(>\mathrm{C}=\mathrm{O})\left(\mathrm{cm}^{-1}\right) ;{ }^{1} \mathrm{H}-\mathrm{NMR}: 1.19(3 \mathrm{H}, \mathrm{t}, J=7.5$, $\left.-\mathrm{OCH}_{2} \underline{\mathrm{CH}}_{3}\right), 3.65\left(2 \mathrm{H}, \mathrm{s},-\underline{\mathrm{C}}_{2} \mathrm{COO}-\right), 3.91\left(3 \mathrm{H}, \mathrm{s},-\mathrm{COOC} \underline{H}_{3}\right), 4.10\left(2 \mathrm{H}, \mathrm{q}, J=7.5,-\mathrm{OC}_{2} \mathrm{CH}_{3}\right), 6.91$ (1H, s, pyrazole- $\underline{\mathrm{H}} 4), 7.12-7.45\left(4 \mathrm{H}, \mathrm{m}\right.$, aromatics); ${ }^{13} \mathrm{C}-\mathrm{NMR}: 14.0$ (q, $\left.-\mathrm{OCH}_{2} \mathrm{C}_{3}\right), 32.0$ (t, - $\underline{\mathrm{C}}_{2} \mathrm{COO}-$ ), 52.0 (q, $\left.-\mathrm{COOC} \underline{H}_{3}\right), 61.5\left(\mathrm{t},-\mathrm{OC}_{2} \mathrm{CH}_{3}\right), 110.1$ (d, pyrazole- $\underline{\mathrm{C}} 4$ ), 116.3-128.0 (a pair of peak at the aromatic region is overlapped), 134.7 (s, aromatic, $\geq \underline{\mathrm{C}}$-pyrazole- $\mathrm{N}_{1}$ ), 137.6 (s, pyrazole- $\underline{5}$ ), 143.8 (s,

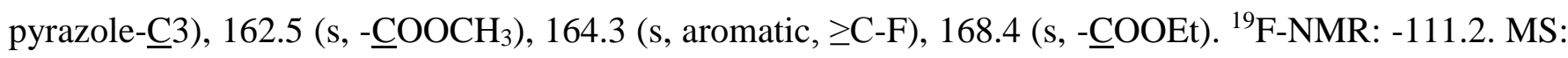
$306 \mathrm{~m} / z\left(\mathrm{M}^{+}\right)$. Anal. Calcd for $\mathrm{C}_{15} \mathrm{H}_{15} \mathrm{FN}_{2} \mathrm{O}_{4}: \mathrm{C}, 58.82 ; \mathrm{H}, 4.94 ; \mathrm{N}, 9.15$. Found: C, 58.88; H, 4.98; N, 9.22 .

1-(4-Nitrophenyl)-3-methoxycarbonyl-5-(ethoxycarbonyl)methylpyrazole $\quad$ (3ca) $\quad\left(\begin{array}{llll}0.49 & \mathrm{~g}, & 73 \%) .\end{array}\right.$ Yellow-orange powder having mp 173-176 ${ }^{\circ} \mathrm{C}$; IR (Nujol): $1740(>\mathrm{C}=\mathrm{O})\left(\mathrm{cm}^{-1}\right) ;{ }^{1} \mathrm{H}-\mathrm{NMR}: 1.24(3 \mathrm{H}, \mathrm{t}, J$ $\left.=6.0,-\mathrm{OCH}_{2} \underline{\mathrm{C}}_{3}\right), 3.79\left(2 \mathrm{H}, \mathrm{s},-\mathrm{C}_{2} \mathrm{COO}-\right), 3.98\left(3 \mathrm{H}, \mathrm{s},-\mathrm{COOC}_{3}\right), 4.17\left(2 \mathrm{H}, \mathrm{q}, J=6.0,-\mathrm{OC}_{2} \mathrm{CH}_{3}\right)$, $7.00(1 \mathrm{H}, \mathrm{s}$, pyrazole- $\underline{\mathrm{H}} 4), 7.74-8.40\left(4 \mathrm{H}, \mathrm{m}\right.$, aromatics); ${ }^{13} \mathrm{C}-\mathrm{NMR}: 14.1$ (q, $\left.-\mathrm{OCH}_{2} \mathrm{CH}_{3}\right), 32.3$ (t, - $\underline{\mathrm{H}}_{2} \mathrm{COO}-$ ), 52.4 (q, - $\mathrm{COO}_{2} \mathrm{H}_{3}$ ), 62.0 (t, - $-\mathrm{OC}_{2} \mathrm{CH}_{3}$ ), 111.5 (d, pyrazole- $\underline{\mathrm{C}} 4$ ), 124.9 (d, aromatic), 126.2

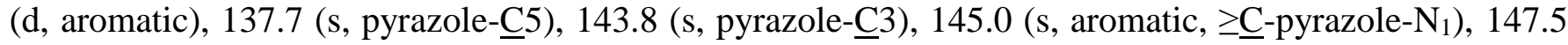
(s, aromatic, $\left.\geq \underline{\mathrm{C}}-\mathrm{NO}_{2}\right), 162.2(\mathrm{~s},-\underline{\mathrm{COOCH}} 3), 168.3$ (s, - $\underline{\mathrm{COOEt}}$ ). MS: $333 \mathrm{~m} / \mathrm{z}\left(\mathrm{M}^{+}\right)$. Anal. Calcd for $\mathrm{C}_{15} \mathrm{H}_{15} \mathrm{~N}_{3} \mathrm{O}_{6}: \mathrm{C}, 54.05 ; \mathrm{H}, 4.54 ; \mathrm{N}, 12.61$. Found: C, 54.11; H, 4.57; N, 12.67.

1-(2-Methylphenyl)-3-methoxycarbonyl-5-(ethoxycarbonyl)methylpyrazole (3da) (0.50 g, 83\%). White powder having mp 98-101 ${ }^{\circ} \mathrm{C}$; IR (Nujol): $1735(>\mathrm{C}=\mathrm{O})\left(\mathrm{cm}^{-1}\right)$; ${ }^{1} \mathrm{H}-\mathrm{NMR}: 1.20(3 \mathrm{H}, \mathrm{t}, J=7.0$, $\left.-\mathrm{OCH}_{2} \mathrm{C}_{3}\right), 2.05\left(3 \mathrm{H}, \mathrm{s},-\mathrm{C}_{6} \mathrm{H}_{4}-\mathrm{C}_{3}\right), 3.51\left(2 \mathrm{H}, \mathrm{s},-\mathrm{C}_{2} 2 \mathrm{COO}-\right), 3.94$ (3H, s, $\left.-\mathrm{COOC} \underline{H}_{3}\right), 4.09$ (2H, q, $J=$ 7.0, $\left.-\mathrm{OCH}_{2} \mathrm{CH}_{3}\right), 6.96(1 \mathrm{H}, \mathrm{s}$, pyrazole- $\underline{\mathrm{H}} 4), 7.23-7.43(4 \mathrm{H}, \mathrm{m}$, the peaks at the aromatic region is

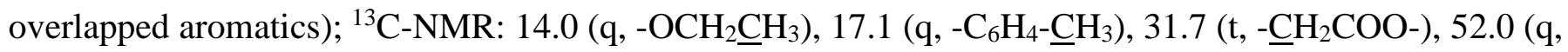
$-\mathrm{COOCH}_{3}$ ), 61.4 (t, - $-\underline{\mathrm{OC}}_{2} \mathrm{CH}_{3}$ ), 109.2 (d, pyrazole- $\left.\underline{\mathrm{C}} 4\right), 126.5$ (d, aromatic), 127.7 (d, aromatic), 130.0

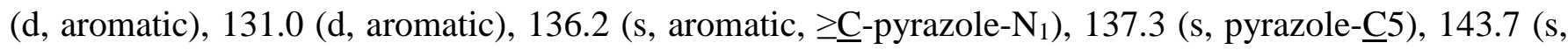

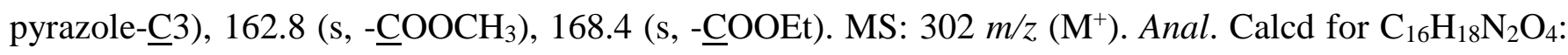
C, 63.56; H, 6.00; N, 9.27. Found: C, 63.51; H, 5.94; N, 9.34.

1-Phenyl-3-methoxycarbonyl-5-(phenylsulfonyl)methylpyrazole (3ab) ${ }^{14}(0.51 \mathrm{~g}, 72 \%)$. ${ }^{1} \mathrm{H}-\mathrm{NMR}: 3.90$ $\left(3 \mathrm{H}, \mathrm{s},-\mathrm{COOC}_{3}\right), 4.42\left(2 \mathrm{H}, \mathrm{s},-\underline{\mathrm{C}}_{2} \mathrm{SO}_{2}-\right), 6.91(1 \mathrm{H}, \mathrm{s}$, pyrazole- $\underline{\mathrm{H}} 4), 7.07-7.66(10 \mathrm{H}, \mathrm{m}$, thef peaks at the aromatic region is overlapped); ${ }^{13} \mathrm{C}-\mathrm{NMR}: 51.7\left(\mathrm{q},-\mathrm{COOC}_{3}\right), 52.2\left(\mathrm{t},-\underline{\mathrm{CH}}_{2} \mathrm{SO}_{2}-\right), 111.4(\mathrm{~d}$, 
pyrazolo-ㄷ4), 125.6 (d, aromatic), 127.9 (d, aromatic), 128.9 (d, aromatic), 132.0 (s, aromatic, $\geq \underline{\mathrm{C}}-\mathrm{SO}_{2}$ ), 133.9 (d, aromatic), 137.1 (s, aromatic, $\geq \underline{\text { C}}-$ pyrazole- $\mathrm{N}_{1}$ ), 137.2 (s, pyrazole-C5), 143.3 (s, pyrazole- $\underline{\mathrm{C}} 3$ ), $161.7\left(\mathrm{~s},-\underline{-} \mathrm{COOCH}_{3}\right)$.

1-(4-Fluorophenyl)-3-methoxycarbonyl-5-(phenylsulfonyl)methylpyrazole (3bb) (0.57 g, $76 \%)$. Pale yellow powder having mp 110-112 ${ }^{\circ} \mathrm{C}$; IR (Nujol): $1735(>\mathrm{C}=\mathrm{O})\left(\mathrm{cm}^{-1}\right)$; ${ }^{1} \mathrm{H}-\mathrm{NMR}: 3.92(3 \mathrm{H}, \mathrm{s}$, $\left.-\mathrm{COOC}_{3}\right), 4.39\left(2 \mathrm{H}, \mathrm{s},-\mathrm{C}_{2} \mathrm{SO}_{2}-\right), 6.86\left(1 \mathrm{H}, \mathrm{s}\right.$, pyrazole- $\left.\underline{H}_{4}\right), 7.05-7.68(9 \mathrm{H}, \mathrm{m}$, the peaks at the aromatic region is overlapped); ${ }^{13} \mathrm{C}-\mathrm{NMR}: 52.1$ (q, $\left.-\mathrm{COOCH}_{3}\right), 52.7$ (t, $\left.-\underline{\mathrm{CH}}_{2} \mathrm{SO}_{2-}\right), 111.7$ (d, pyrazole-ㄷ4), 116.1 (d, aromatic), 116.4 (d, aromatic), 128.4 (d, aromatics), 129.4 (d, aromatic), 132.4 (s, aromatic, $\geq \underline{\mathrm{C}}-\mathrm{SO}_{2}$ ), 133.6 (s, aromatic, $\geq \underline{\mathrm{C}}$-pyrazole- $\mathrm{N}_{1}$ ), 134.4 (d, aromatic), 137.5 (s, pyrazole- $\underline{\mathrm{C}} 5$ ), 143.9 (s, pyrazole-C3), 161.1 (s, - $\underline{\mathrm{COOCH}_{3}}$ ), 164.5 (s, aromatic, $\left.\geq \underline{\mathrm{C}}-\mathrm{F}\right) ;{ }^{19} \mathrm{~F}-\mathrm{NMR}\left(\mathrm{CDCl}_{3}\right):-110.3$. MS: $374 \mathrm{~m} / \mathrm{z}\left(\mathrm{M}^{+}\right)$. Anal. Calcd for $\mathrm{C}_{18} \mathrm{H}_{15} \mathrm{FN}_{2} \mathrm{O}_{4} \mathrm{~S}$ : C, 57.75; H, 4.04; N, 7.48. Found: C, 57.80; H, 3.99; N, 7.52 .

1-(4-Nitrophenyl)-3-methoxycarbonyl-5-(phenylsulfonyl)methylpyrazole (3cb) (0.60 g, 75\%). Yellow powder having mp 169-171 ${ }^{\circ} \mathrm{C}$; IR (Nujol): $1740(>\mathrm{C}=\mathrm{O})\left(\mathrm{cm}^{-1}\right) ;{ }^{1} \mathrm{H}-\mathrm{NMR}: 3.95\left(3 \mathrm{H}, \mathrm{s},-\mathrm{COOC} \underline{H}_{3}\right), 4.48$ $\left(2 \mathrm{H}, \mathrm{s},-\mathrm{C}_{2} \mathrm{SO}_{2}-\right), 6.86(1 \mathrm{H}, \mathrm{s}$, pyrazole- $\underline{\mathrm{H}} 4), 7.51-8.33\left(9 \mathrm{H}, \mathrm{m}\right.$, aromatics); ${ }^{13} \mathrm{C}-\mathrm{NMR}: 52.4$ (q, - $\left.\mathrm{COOC}_{3}{ }_{3}\right), 52.8$ (t, - $\underline{\mathrm{CH}}_{2} \mathrm{SO}_{2}$ ), 114.0 (d, pyrazole- $\underline{\mathrm{C}} 4$ ), 124.9 (d, aromatic), 126.9 (d, aromatic), 128.5 (d, aromatic), 129.6 (d, aromatic), 132.6 (s, aromatic, $\geq \underline{\mathrm{C}}-\mathrm{SO}_{2}-$ ), 134.7 (d, aromatic), 137.4 (s, pyrazole- $\underline{\mathrm{C}} 5$ ), 142.6 (s, pyrazole-ㅡㅡ), 145.1 (s, aromatic, $\geq \underline{\text { C-pyrazole- }} \mathrm{N}_{1}$ ), 148.0 (s, aromatic, $\geq \underline{\mathrm{C}}-\mathrm{NO}_{2}$ ), 161.8 (s, - $\left.\mathrm{COOCH}_{3}\right)$. MS: $401 \mathrm{~m} / \mathrm{z}\left(\mathrm{M}^{+}\right)$. Anal. Calcd for $\mathrm{C}_{18} \mathrm{H}_{15} \mathrm{~N}_{3} \mathrm{O}_{6} \mathrm{~S}$ : C, 53.86; H, 3.77; N, 10.47. Found: C, $53.81 ; \mathrm{H}, 3.82 ; \mathrm{N}, 10.42$.

1-(2-Methylphenyl)-3-methoxycarbonyl-5-(phenylsulfonyl)methylpyrazole (3db) (0.56 g, $75 \%)$. Yellow powder having mp 104-106 ${ }^{\circ} \mathrm{C}$; IR (Nujol): $1730(>\mathrm{C}=\mathrm{O})\left(\mathrm{cm}^{-1}\right) ;{ }^{1} \mathrm{H}-\mathrm{NMR}: 1.83(3 \mathrm{H}, \mathrm{s}$, $\left.-\mathrm{C}_{6} \mathrm{H}_{4}-\underline{\mathrm{C}}_{3}\right), 3.88\left(3 \mathrm{H}, \mathrm{s},-\mathrm{COOC}_{3}\right), 4.22\left(2 \mathrm{H}, \mathrm{br}\right.$ s, $-\mathrm{C}_{2} \mathrm{SO}_{2}-$, becomes a sharp singlet at $\left.333^{\circ} \mathrm{K}\right), 6.68$ $(1 \mathrm{H}, \mathrm{m}$, aromatic), $7.94(1 \mathrm{H}, \mathrm{s}$, pyrazole- $\underline{\mathrm{H}} 4), 7.09-7.66(8 \mathrm{H}, \mathrm{m}$, the peaks at the aromatic region is overlapped); ${ }^{13} \mathrm{C}-\mathrm{NMR}: 16.9$ (q, $\left.-\mathrm{C}_{6} \mathrm{H}_{4}-\underline{\mathrm{CH}}_{3}\right), 52.1$ (q, $\left.-\mathrm{COOC}_{3}\right), 52.6\left(\mathrm{t},-\mathrm{CH}_{2} \mathrm{SO}_{2}\right.$ ) $), 110.8$ (d, pyrazole-C44), 126.6 (d, aromatic), 127.8 (d, aromatic), 128.6 (d, aromatic), 129.4 (d, aromatic), 130.3 (d, aromatic), 131.1 (d, aromatic), 133.0 (s, aromatic, C-Me), 134.4 (d, aromatic), 136.1 (s, aromatic,

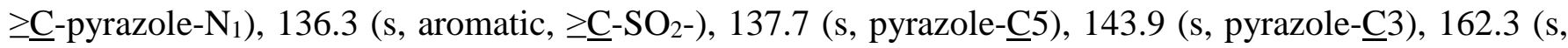
- $\left.\mathrm{COOCH}_{3}\right)$. MS: $370 \mathrm{~m} / \mathrm{z}\left(\mathrm{M}^{+}\right)$. Anal. Calcd for $\mathrm{C}_{19} \mathrm{H}_{18} \mathrm{~N}_{2} \mathrm{O}_{4} \mathrm{~S}: \mathrm{C}, 61.61 ; \mathrm{H}, 4.90 ; \mathrm{N}, 7.56$. Found: C, $61.57 ; \mathrm{H}, 4.88 ; \mathrm{N}, 7.60$.

1-Phenyl-3-methoxycarbonyl-5-[(2-acetylaminophenyl)sulfonyl]methylpyrazole (3ac) $)^{4}(0.60 \mathrm{~g}, 73 \%)$. ${ }^{1} \mathrm{H}-\mathrm{NMR}: 2.06\left(3 \mathrm{H}, \mathrm{s},-\mathrm{COC} \underline{H}_{3}\right), 3.95\left(3 \mathrm{H}, \mathrm{s},-\mathrm{COOC}_{3}\right), 4.48\left(2 \mathrm{H}, \mathrm{s},-\mathrm{C}_{2} \mathrm{SO}_{2}-\right), 6.99(1 \mathrm{H}, \mathrm{s}$, pyrazole- $\underline{\mathrm{H}} 4), 7.13-8.53(9 \mathrm{H}, \mathrm{m}$, some peaks at the aromatic region is overlapped), $9.30(1 \mathrm{H}$, br s,

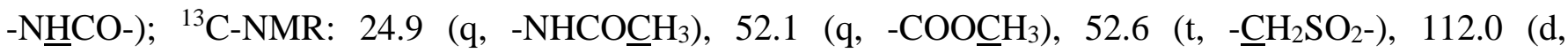




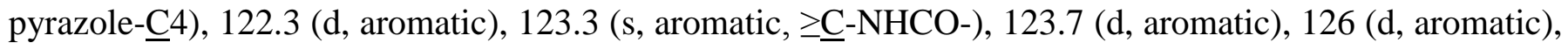
129.4 (d, aromatic), 129.6 (d, aromatic), 130.3 (d, aromatic), 131.2 (s, aromatic, $\geq \underline{\mathrm{C}-}-\mathrm{SO}_{2}-$ ), 136.0 (d,

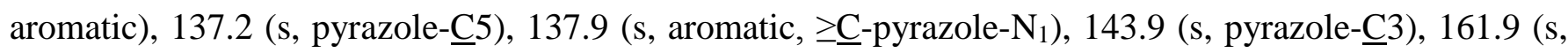
$\left.-\underline{\mathrm{COOCH}}_{3}\right), 168.0$ (s, -NHCO-).

\section{1-(4-Fluorophenyl)-3-methoxycarbonyl-5-[(2-acetylaminophenyl)sulfonyl]methylpyrazole}

(3bc)

(0.69 g, 80\%). Pale yellow powder having mp 137-140 ${ }^{\circ} \mathrm{C}$; IR (Nujol): 3370 (amide N-H), 1740 (ester $>\mathrm{C}=\mathrm{O}), 1705($ amide $>\mathrm{C}=\mathrm{O})\left(\mathrm{cm}^{-1}\right) ;{ }^{1} \mathrm{H}-\mathrm{NMR}: 2.11\left(3 \mathrm{H}, \mathrm{s},-\mathrm{COC}_{3}\right), 3.96\left(3 \mathrm{H}, \mathrm{s},-\mathrm{COOC}_{3}\right), 4.45(2 \mathrm{H}, \mathrm{s}$, $\left.-\underline{C}_{2} \mathrm{SO}_{2-}\right), 6.94(1 \mathrm{H}, \mathrm{s}$, pyrazole- $\underline{\mathrm{H}} 4), 7.10-8.52(8 \mathrm{H}, \mathrm{m}$, some peaks at the aromatic region is

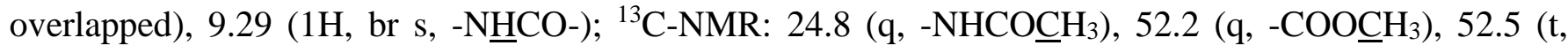
- $\underline{\mathrm{CH}}_{2} \mathrm{SO}_{2-}$ ), 112.1 (d, pyrazole-C4), 116.1 (d, aromatic), 116.3 (d, aromatic), 122.5 (d, aromatic), 123.5 (s,

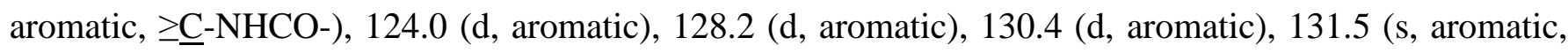
$\geq \underline{\mathrm{C}}-\mathrm{SO}_{2}$ ), 133.3 (s, aromatic, $\geq \underline{\mathrm{C}}$-pyrazole- $\mathrm{N}_{1}$ ), 136.0 (d, aromatic), 137.9 (s, pyrazole- $\underline{\mathrm{C}} 5$ ), 144.1 (s,

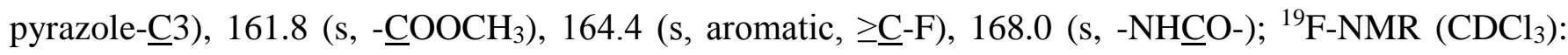
-110.0. MS: $431 \mathrm{~m} / \mathrm{z}\left(\mathrm{M}^{+}\right)$. Anal. Calcd for $\mathrm{C}_{20} \mathrm{H}_{18} \mathrm{FN}_{3} \mathrm{O}_{5} \mathrm{~S}: \mathrm{C}, 55.68 ; \mathrm{H}, 4.21 ; \mathrm{N}, 9.74$. Found: C, 55.73; $\mathrm{H}$, $4.17 ; \mathrm{N}, 9.69$.

1-(4-Nitrophenyl)-3-methoxycarbonyl-5-[(2-acetylaminophenyl)sulfonyl]methylpyrazole (3cc) (0.69 g, 77\%). Yellow-orange powder having mp 189-193 ${ }^{\circ} \mathrm{C}$; IR (Nujol): 3350 (amide N-H), 1740 (ester $>\mathrm{C}=\mathrm{O}), 1710$ (amide >C=O) $\left(\mathrm{cm}^{-1}\right)$; ${ }^{1} \mathrm{H}-\mathrm{NMR}: 2.09\left(3 \mathrm{H}, \mathrm{s},-\mathrm{COCH}_{3}\right), 3.96\left(3 \mathrm{H}, \mathrm{s},-\mathrm{COOC}_{3}\right), 4.55(2 \mathrm{H}, \mathrm{s}$, $\left.-\underline{\mathrm{H}}_{2} \mathrm{SO}_{2-}\right), 6.93(1 \mathrm{H}, \mathrm{s}$, pyrazole- $\underline{\mathrm{H}} 4), 7.10-8.43(8 \mathrm{H}, \mathrm{m}$, some peaks at the aromatic region is

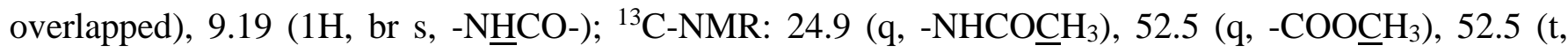

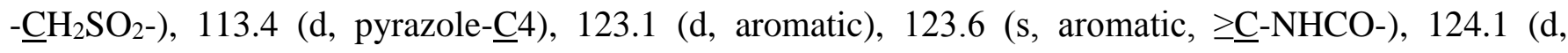
aromatic), 125.0 (d, aromatic), 126.6 (d, aromatic), 130.4 (d, aromatic), 131.8 (s, aromatic, $\geq \underline{\mathrm{C}}-\mathrm{SO}_{2}$ ), 136.3 (d, aromatic), 137.9 (s, pyrazole-C5), 142.3 (s, aromatic, $\geq \underline{\mathrm{C}}$-pyrazole- $\mathrm{N}_{1}$ ), 145.2 (s, pyrazole- 3 ), 147.9 (s, aromatic, $\geq \underline{\mathrm{C}}-\mathrm{NO}_{2}$ ), 161.5 (s, - $\left.\mathrm{COOCH}_{3}\right), 168.1$ (s, -NHCOO-). MS: $458 \mathrm{~m} / z\left(\mathrm{M}^{+}\right)$. Anal. Calcd for $\mathrm{C}_{20} \mathrm{H}_{18} \mathrm{~N}_{4} \mathrm{O}_{7} \mathrm{~S}$ : C, 52.40; H, 3.96; N, 12.22. Found: C, 52.44; H, 3.99; N, 12.17 .

\section{1-(2-Methylphenyl)-3-methoxycarbonyl-5-[(2-acetylaminophenyl)sulfonyl]methylpyrazole}

(3dc)

(0.64 g, 75\%). Pale yellow powder having mp 144-146 ${ }^{\circ} \mathrm{C}$; IR (Nujol): 3360 (amide N-H), 1730 (ester $>\mathrm{C}=\mathrm{O}), 1700$ (amide $>\mathrm{C}=\mathrm{O})\left(\mathrm{cm}^{-1}\right) ;{ }^{1} \mathrm{H}-\mathrm{NMR}: 1.90\left(3 \mathrm{H}, \mathrm{s}, \geq \mathrm{C}-\mathrm{C}_{3}\right), 2.05\left(3 \mathrm{H}, \mathrm{s},-\mathrm{COC}_{3}\right), 3.93(3 \mathrm{H}, \mathrm{s}$, $\left.-\mathrm{COOC} \underline{H}_{3}\right), 4.38\left(2 \mathrm{H}\right.$, br s, $-\underline{\mathrm{CH}}_{2} \mathrm{SO}_{2^{-}}$, becomes a sharp singlet at $\left.333 \mathrm{~K}\right), 6.83(1 \mathrm{H}, \mathrm{m}$, aromatic), 7.00 $(1 \mathrm{H}, \mathrm{s}$, pyrazole- $\underline{\mathrm{H}} 4), 7.15-8.54(7 \mathrm{H}, \mathrm{m}$, some peaks at the aromatic region is overlapped), $9.29(1 \mathrm{H}, \mathrm{br} \mathrm{s}$,

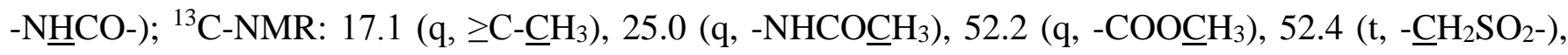
111.2 (d, pyrazole-ㄷ4), 122.6 (d, aromatic), 123.6 (s, aromatic, $\geq \underline{\mathrm{C}}-\mathrm{NHCO}$-), 123.9 (d, aromatic), 126.9 (d, aromatic), 127.8 (d, aromatic), 130.4 (d, aromatic), 130.7 (a pair of peaks at the aromatic region is overlapped), 131.7 (s, aromatic, $\left.\geq \underline{\mathrm{C}}-\mathrm{SO}_{2}-\right), 132.4$ (s, aromatic, $\left.\geq \underline{\mathrm{C}}-\mathrm{CH}_{3}\right), 136.1$ (s, pyrazole- $\left.\underline{\mathrm{C}} 5\right), 136.2$ (d, 
aromatic), 138.0 (s, aromatic, $\geq \underline{\mathrm{C}}-$ pyrazole- $\left.\mathrm{N}_{1}\right), 144.1$ (s, pyrazole- $\left.\underline{\mathrm{C}} 3\right), 162.2\left(\mathrm{~s},-\underline{\mathrm{COOCH}_{3}}\right), 168.2(\mathrm{~s}$, -NHCO-). MS: $427 \mathrm{~m} / z\left(\mathrm{M}^{+}\right)$. Anal. Calcd for $\mathrm{C}_{21} \mathrm{H}_{21} \mathrm{~N}_{3} \mathrm{O}_{5} \mathrm{~S}: \mathrm{C}, 59.00 ; \mathrm{H}, 4.95 ; \mathrm{N}, 9.83$. Found: C, 58.97; $\mathrm{H}, 4.91 ; \mathrm{N}, 9.85$.

In the case of entries 13,14 of Table 2, the residue was chromatographed on a silica gel column with hexane/EtOAc 3:2. First fractions contained starting 1a, further elution gave complex mixtures of untractable tarry materials.

Copper(I)-catalysed reaction between hydrazonoyl chloride (1a) and terminal alkynes 4a,b. General procedure. In a clear, colourless solution of the appropriate terminal alkyne 4a,b (2.0 mmol) and triethylamine $(0.20 \mathrm{~g}, 2.0 \mathrm{mmol})$ in dry $\mathrm{CH}_{2} \mathrm{Cl}_{2}(4 \mathrm{~mL})$ was added $\mathrm{CuCl}(10 \mathrm{mg}, 0.1 \mathrm{mmol})$ under vigorous magnetic stirring obtaining a bright yellow subspension. A solution of the hydrazonoyl chloride (1a) $(0.42 \mathrm{~g}, 2.0 \mathrm{mmol})$ in dry $\mathrm{CH}_{2} \mathrm{Cl}_{2}(4 \mathrm{~mL})$ was added dropwise to the yellow subspension and the mixture was stirred at $20{ }^{\circ} \mathrm{C}$ for $1 \mathrm{~h}$. The crude was filtered over a silica gel pad and the solvent was evaporated under reduced pressure. The residue was chromatographed on a silica gel column with hexane/EtOAc 2:1. Crystallisation of the eluate with $i \operatorname{Pr}_{2} \mathrm{O}$ gave pure 3ad and 3ae.

1-Phenyl-3-methoxycarbonyl-5-(cyclohexyl)methylpyrazole (3ad) (0.40 g, 67\%). White powder having mp 87-88 ${ }^{\circ} \mathrm{C}$; IR (Nujol): 1735 (>C=O) $\left(\mathrm{cm}^{-1}\right)$; ${ }^{1} \mathrm{H}-\mathrm{NMR}: 0.80-1.64$ (11H, m, cyclohexyl), 2.49 $\left(2 \mathrm{H}, \mathrm{d}, J=6.0\right.$, pyrazole- $\left.\underline{\mathrm{H}}_{2}\right), 3.90\left(3 \mathrm{H}, \mathrm{s},-\mathrm{COOC}_{3}\right), 6.75\left(1 \mathrm{H}, \mathrm{s}\right.$, pyrazole- $\left.\underline{\mathrm{H}}_{4}\right), 7.37-7.46(5 \mathrm{H}, \mathrm{m}$, the peaks at the aromatic region is overlapped); ${ }^{13} \mathrm{C}-\mathrm{NMR}$ : 26.0-32.9 (cyclohexyl - $\underline{\mathrm{CH}}_{2}$ ), 33.5 (t, pyrazole

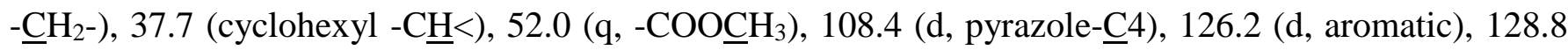
(d, aromatic), 129.1 (d, aromatic), 139.2 (s, aromatic, $\geq \underline{\text { C-pyrazole-N }}$ ), 143.4 (s, pyrazole- $\underline{\text { 5 }}$ ), 144.61 (s,

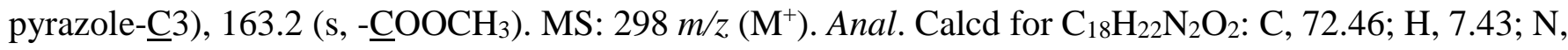
9.39. Found: C, 72.41; H, 7.39; N, 9.44.

1-Phenyl-3-methoxycarbonyl-5-(methoxy)methylpyrazole (3ae) (0.30 g, 61\%). White powder having mp 98-100 ${ }^{\circ} \mathrm{C}$; IR (Nujol): $1730(>\mathrm{C}=\mathrm{O})\left(\mathrm{cm}^{-1}\right) ;{ }^{1} \mathrm{H}-\mathrm{NMR}: 3.37\left(3 \mathrm{H}, \mathrm{s},-\mathrm{OC} \underline{\mathrm{H}}_{3}\right), 3.94\left(3 \mathrm{H}, \mathrm{s},-\mathrm{COOC} \underline{\mathrm{H}}_{3}\right)$, $4.39\left(2 \mathrm{H}, \mathrm{s},-\mathrm{C}_{2} \mathrm{OMe}\right), 7.01(1 \mathrm{H}, \mathrm{s}$, pyrazole- $\underline{\mathrm{H}} 4), 7.43-7.62(5 \mathrm{H}, \mathrm{m}$, some peaks at the aromatic region is overlapped); ${ }^{13} \mathrm{C}-\mathrm{NMR}: 52.1\left(\mathrm{q},-\mathrm{COOC}_{3}\right), 57.9\left(\mathrm{q},-\underline{\mathrm{O}}^{\mathrm{C}} \mathrm{H}_{3}\right), 64.3\left(\mathrm{t},-\underline{\mathrm{CH}}_{2} \mathrm{OMe}\right), 111.2(\mathrm{~d}$, pyrazole-C44), 125.0 (d, aromatic), 128.8 (d, aromatic), 129.2 (d, aromatic), 138.9 (s, aromatic,

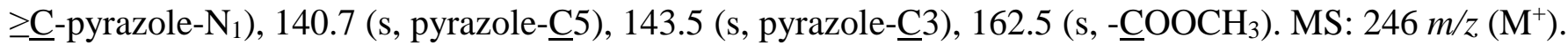
Anal. Calcd for $\mathrm{C}_{13} \mathrm{H}_{14} \mathrm{~N}_{2} \mathrm{O}_{3}$ : C, 63.40; H, 5.73; N, 11.38. Found: C, 63.43; H, 5.70; N, 11.42.

\section{ACKNOWLEDGEMENTS}

Thanks are due to Dr. Lara de Benassuti, University of Milan, who accomplished NMR spectra. 
G.M. was financially supported by the Department of Chemistry of the Università degli Studi di Milano (PSR2019_DIP_005_PI).

\section{REFERENCES AND NOTES}

1. 'Modern Allene Chemistry,' ed. by N. Krause and A. S. K. Hashmi, Wiley-VCH Verlag, Weinheim, 2004, Vol. 2, pp. 593-994.

2. K. N. Houk, F. Liu, Z. Yang, and J. I. Seeman, Angew. Chem. Int. Ed., 2021, 60, 12660.

3. (a) G. Broggini and G. Zecchi, Gazz. Chim. Ital., 1996, 126, 479; (b) M. Breugst and H.-U. Reissig, Angew. Chem. Int. Ed., 2020, 59, 12293.

4. G. Broggini and G. Molteni, J. Chem. Soc., Perkin Trans. 1, 2000, 1685.

5. (a) A. Ansari, A. Ali, and M. Asif, New J. Chem., 2017, 41, 16; (b) K. Karrouchi, S. Radi, Y. Ramli, J. Taoufik, Y. N. Mabkhot, and F. A. Al-aizari, Molecules, 2018, 23, 134.

6. C. Jamieson and K. Livingstone, 'The Nitrile Imine 1,3-Dipole,' Springer International Publishing, Heidelberg, 2020.

7. S. M. Mitchell, K. A. N. Sachinthani, R. Pulukkody, and E. B. Pentzer, ACS Macro Lett., 2020, 9, 1046.

8. G. Molteni, Heterocycles, 2020, 100, 1249.

9. R. Blieck, M. Taillefer, and F. Monnier, J. Org. Chem., 2019, 84, 11247.

10. G. Nagendrappa, G. C. Joshi, and D. Devaprabhakara, J. Organomet. Chem., 1971, $27,421$.

11. F. Alonso, Y. Moglie, and G. Radivoy, Acc. Chem. Res., 2015, 48, 2516.

12. (a) Compound 1a and 1d: M. T. Cocco, A. Maccioni, and A. Plumitallo, Farmaco, Ed. Sci., 1985, 40, 272; (b) compound 1b: M. M. El-Abadelah, A. Q. Hussein, M. R. Kamal, and K. H. Al-Adhami, Heterocycles, 1988, 27, 917; (c) compound 1c: M. M. El-Abadelah, A. Q. Hussein, and B. A. Ahmad, Heterocycles, 1991, 32, 1879.

13. (a) Compound 2b: G. Pourcelot and P. Cadiot, Bull. Soc. Chim. Fr., 1966, 9, 3024; (b) compound 2c: G. Broggini, G. Molteni, and G. Zecchi, J. Org. Chem., 1994, 59, 8271.

14. Compound 3ab: L. Bruchè and G. Zecchi, J. Heterocycl. Chem., 1983, 20, 1705. 